\title{
Estimation of Production Function and Technical Efficiency Shallot Farming
}

\author{
Muhammad Fajar' ${ }^{1}$, Oktya Putri Gitaningtyas ${ }^{2}$, Muhammad Muhtoni ${ }^{3}$, \\ Purwaning Dhahari ${ }^{4}$ \\ Badan Pusat Statistik,mfajar@bps.go.id ${ }^{1}$ \\ Badan Pusat Statistik, oktyaputri@bps.go.id ${ }^{2}$ \\ Badan Pusat Statistik, muhtoni@bps.go.id \\ Badan Pusat Statistik, dhahari@bps.go.id ${ }^{4}$
}

doi: https://doi.org/10.15642/mantik.2019.5.1.50-59

\begin{abstract}
Abstrak: Bawang merah merupakan salah satu komoditas potensi hortikultura. Tujuan studi ini adalah untuk mengestimasi fungsi produksi dan efisiensi usaha tani bawang merah. Metode yang digunakan dalam penelitian adalah estimasi fungsi produksi dengan menggunakan stochastic frontier. Data yang digunakan dalam penelitian ini adalah produksi bawang merah $(\mathrm{kg})$, luas panen $\left(\mathrm{m}^{2}\right)$, tenaga kerja yang digunakan $(\mathrm{HOK})$, penggunaan benih $(\mathrm{kg})$, pupuk $(\mathrm{kg})$, pestisida yang digunakan $(\mathrm{kg})$, bersumber dari SHR2014 yang dilakukan Badan Pusat Statistik. Dalam proses estimasi seluruh variabel ditransformasi logaritma natural. Hasil penelitian menunjukan bahwa estimasi fungsi produksi bawang merah baik untuk musim kemarau maupun musim hujan dengan variabel independen meliputi luas panen, tenaga kerja, benih, pupuk, dan pestisida signifikan dalam model sehingga model yang terbentuk valid untuk digunakan lebih lanjut. rata-rata efisiensi teknis usaha tani bawang merah pada musim kemarau dan hujan masing-masing sebesar 0.6626 dan 0.6627 yang berarti secara umum usaha tani bawang merah di Indonesia tidak efisien dari sisi teknis. Artinya, terdapat indikasi bahwa teknologi pengolahan optimal input produksi dalam usaha belum dilakukan secara optimal.
\end{abstract}

Kata kunci: fungsi produksi, efisiensi teknis, bawang merah.

\begin{abstract}
Shallot is one of the potential horticultural commodities. The purpose of this study is to estimate the production function and efficiency of shallot farming. The method used in the study is the estimation of production functions using stochastic frontier. The data used in this study were shallot production $(\mathrm{kg})$, harvested area $(\mathrm{m} 2)$, labor used $(\mathrm{HOK})$, use of seeds $(\mathrm{kg})$, fertilizer $(\mathrm{kg})$, pesticides used $(\mathrm{kg})$, sourced from SHR2014 which conducted by the Central Statistics Agency. In the estimation process, all variables are transformed by natural logarithms. The results showed that the estimation of the function of shallot production for both the dry season and the wet season with independent variables included harvested area, labor, seeds, fertilizers, and significant pesticides in the model, so that formed model was valid for further use. The average technical efficiency of shallot farming in the dry and wet season is 0.6626 and 0.6627 , respectively, which means that in general, shallot farming in Indonesia is not efficient on the technical side. That is, there are indications that the optimal processing technology of production inputs in the business has not been carried out optimally.
\end{abstract}

Keywords: production function, technical efficiency, shallots. 


\section{Introduction}

The horticulture sub-sector is one of the agricultural sub-sectors, which includes fruit, vegetables, medicinal plants, and ornamental plants of a very diverse type compared to the food crop subsector and plantations. However, the contribution of the horticulture subsector seen from Indonesia's Gross Domestic Product (GDP) during 2014 - 2018 was only in the range of 1.49 percent, smaller than the contribution of the food crops and plantation subsectors (Figure 1). This shows that the horticulture sub-sector still has not contributed significantly to the overall economy.

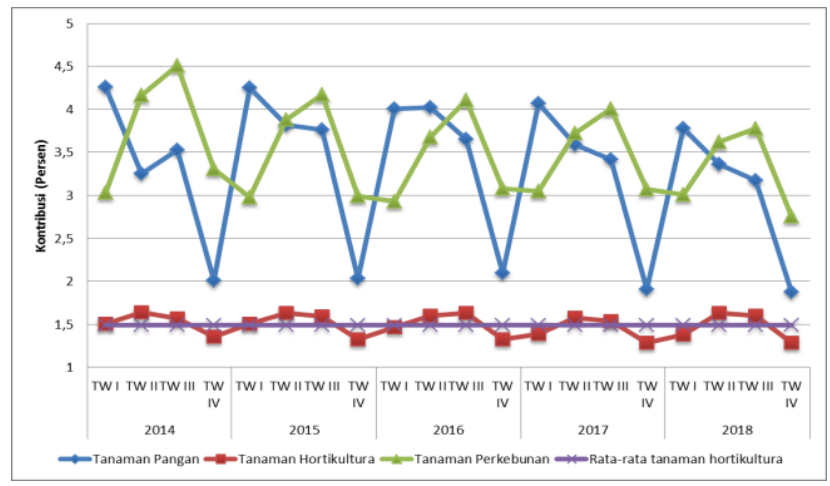

Figure 1. The contribution of food crops, horticulture, and estate crops subsectors to GDP for the 2014-2018 period

Shallot is one of the potential horticultural commodities. From 2013 to 2017, the shallot production index tended to increase (Figure 2). This indicates that the trend of commodity production during the observation period has increased. The increase in shallot production cannot be separated from the efforts of the farmers. However, it is not yet known whether the efforts made by farmers have been efficient or not efficient. Therefore, in this study, the authors estimated the shallot production function using the stochastic frontier model so that from the model we can obtain the magnitude of shallot farming efficiency in Indonesia, both during the dry season and the wet season.

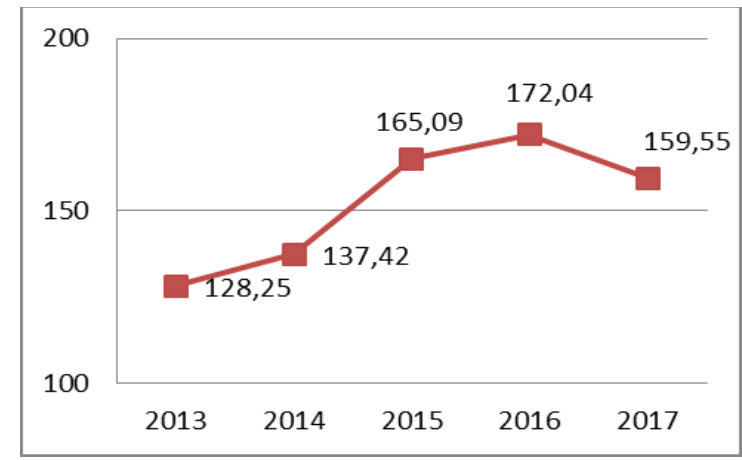

Source: Agricultural Indicators, 2017

Figure 2. The growth of Indonesian Shallot Production Index

\section{Research methods}

\subsection{Cobb-Douglas Stochastics Frontier}

A stochastic frontier function is formulated as follows:

$$
y_{i}{ }^{*}=f\left(\boldsymbol{x}_{\boldsymbol{i}} ; \boldsymbol{\beta}\right) \exp \varepsilon_{i}
$$


In equation (1) there is a component $f\left(\boldsymbol{x}_{\boldsymbol{i}} ; \boldsymbol{\beta}\right)$ Which is assumed to be the Cobb-Douglas function. Then equation (1) is transformed into a natural logarithm as follows:

$$
y_{i}=\boldsymbol{\beta}^{\prime} \boldsymbol{x}_{i}+\varepsilon_{i}
$$

In equation (2) $\boldsymbol{x}_{\boldsymbol{i}}$ is production input vector $(j \times 1) . j$ is the number of independent variables (production factors) and $y_{i}{ }^{*}$ Is the production produced by the observation (business unit) $i$. The component $\varepsilon_{i}$ is described as a component $v_{i}$ and $u_{i}$ by specifying that: $\varepsilon_{i}=v_{i}+u_{i}$ and $i$ states the observation (business unit) $i$. According to reference [6] addition $\left(v_{i}+u_{i}\right)$ reflecting technical efficiency and $u_{i}$ reflect the effects of technical inefficiencies and $u_{i} \leq 0 . u_{i}$ following a normal truncated distribution $\left(u_{i} \sim N^{+}\left(\mu, \sigma_{u}^{2}\right)\right)$ and $v_{i}$ assumed to first follow a normal distribution $\left(v_{i} \sim N\left(0, \sigma_{v}^{2}\right)\right)[10]$. According to reference [3] equation (2) has the log-likelihood function and the first derivative of the log-likelihood function as follows:

$$
\begin{gathered}
\ln L=n \ln \frac{\sqrt{2}}{\sqrt{\pi}}+n \ln \sigma^{-1}+\sum_{i=1}^{n} \ln 1-F^{*}\left(\left(y_{i}-\boldsymbol{\beta}^{\prime} \boldsymbol{x}_{i}\right) \lambda \sigma^{-1}\right)-\frac{1}{2 \sigma^{2}} \sum_{i=1}^{n}\left(y_{i}-\boldsymbol{\beta}^{\prime} \boldsymbol{x}_{i}\right)^{2} \\
\frac{\partial \ln L}{\partial \sigma^{2}}=-\frac{n}{2 \sigma^{2}}+\frac{1}{2 \sigma^{4}} \sum_{i=1}^{n}\left(y_{i}-\boldsymbol{\beta}^{\prime} \boldsymbol{x}_{i}\right)^{2}+\frac{\lambda}{2 \sigma^{3}} \sum_{i=1}^{n} \frac{f_{i}^{*}}{\left(1-F_{i}^{*}\right)}\left(y_{i}-\boldsymbol{\beta}^{\prime} \boldsymbol{x}_{i}\right) \\
\frac{\partial \ln L}{\partial \lambda}=-\frac{1}{\sigma} \sum_{i=1}^{n} \frac{f_{i}^{*}}{\left(1-F_{i}^{*}\right)}\left(y_{i}-\boldsymbol{\beta}^{\prime} \boldsymbol{x}_{i}\right) \\
\frac{\partial \ln L}{\partial \boldsymbol{\beta}}=\frac{1}{\sigma^{2}} \sum_{i=1}^{n}\left(y_{i}-\boldsymbol{\beta}^{\prime} \boldsymbol{x}_{i}\right) \boldsymbol{x}_{i}+\frac{\lambda}{\sigma} \sum_{i=1}^{n} \frac{f_{i}^{*}}{\left(1-F_{i}^{*}\right)}\left(y_{i}-\boldsymbol{\beta}^{\prime} \boldsymbol{x}_{i}\right) \boldsymbol{x}_{\boldsymbol{i}}
\end{gathered}
$$

by: $n$ is the number of observation samples, $\sigma^{2}=\sigma_{u}^{2}+\sigma_{v}^{2}, \lambda=\sigma_{u}^{2} / \sigma_{v}^{2}, \gamma=\sigma_{u}^{2} / \sigma^{2} f^{*}($. declare standard normal $\operatorname{pdf}\left[f_{i}^{*}=f^{*}\left(\left(y_{i}-\boldsymbol{\beta}^{\prime} \boldsymbol{x}_{i}\right) \lambda \sigma^{-1}\right)\right]$, and $F^{*}($.$) declare the default$ normal cdf $\left[F_{i}^{*}=F^{*}\left(\left(y_{i}-\boldsymbol{\beta}^{\prime} \boldsymbol{x}_{i}\right) \lambda \sigma^{-1}\right)\right]$.

In equation (4) it becomes maximum when the component:

$$
\sum_{i=1}^{n} \frac{f_{i}^{*}}{\left(1-F_{i}^{*}\right)}\left(y_{i}-\boldsymbol{\beta}^{\prime} \boldsymbol{x}_{i}\right)=0,
$$

enter these results into equation (3) so that:

$$
\frac{\partial \ln L}{\partial \sigma^{2}}=-\frac{n}{2 \sigma^{2}}+\frac{1}{2 \sigma^{4}} \sum_{i=1}^{n}\left(y_{i}-\boldsymbol{\beta}^{\prime} \boldsymbol{x}_{i}\right)^{2},
$$

from equation (6) obtained:

$$
\hat{\sigma}^{2}=\frac{1}{n} \sum_{i=1}^{n}\left(y_{i}-\boldsymbol{\beta}^{\prime} \boldsymbol{x}_{i}\right)^{2}
$$

The determination of $\boldsymbol{\beta}$ estimation cannot be direct as in the determination $\hat{\sigma}^{2}$ however $\hat{\sigma}^{2}$ depends on $\boldsymbol{\beta}$ and estimation $\lambda$ depends on $\beta$ and $\hat{\sigma}^{2}$, so to get a solution in equations (4), (5), and (6) that must implement nonlinear optimization so that numerical optimization is needed involving an iterative process where the value $\sigma^{2}>0, \boldsymbol{\beta}>\mathbf{0}$, and $\lambda>0$. In this study to find solutions in equations (4), (5), and (6), so the authors use package npsf. 
Package npsf is used to get parameter estimates of stochastics frontier equation (2) and technical efficiency.

\subsection{Technical Efficiency (TE)}

Technical efficiency will be achieved if the entrepreneur can allocate production factors in such a way that high results can be achieved [4]. Technical efficiency is defined as producing more, with the same input or producing the same number of outputs with fewer inputs [9]. Technical efficiency requires or requires a production process that can take advantage of fewer inputs to produce output in the same amount [1]. So the use of production factors is said to be technically efficient if the production factors used to produce maximum production. Technical efficiency is formulated as follows:

$$
T E_{i}=\frac{y_{i}{ }^{*}}{{y_{l}}^{*}}
$$

with $\hat{y}_{i}$ Is the potential output (fitted value) by observation ke-i. Equation (9) state the technical efficiency of each observation so that it needs to be represented as an average. The technical efficiency mean is formulated:

$$
T E=E\left[\exp \left(-u_{i} \mid \varepsilon_{i}\right)\right]
$$

If the value of technical efficiency is greater than 0.7 , then a farm can be said to be quite efficient [8], and if the value of technical efficiency is more than 0.8 , it can be said to be efficient [1].

\subsection{Data source}

The data used in this study are secondary data and cross sections, namely data on the results of The Cost Structure of Strategic Horticultural Commodities 2014 (ST2013SHR.S 2014), Statistic Indonesia. The input-output variables are from ST2013-SHR. The one used is $y^{*}$ : Shallot production $(\mathrm{kg}), x_{1}$ : harvested area $\left(\mathrm{m}^{2}\right), x_{2}$ : labor used (HOK), $x_{3}$ : seed use $(\mathrm{kg}), x_{4}$ : fertilizer $(\mathrm{kg}), x_{5}$ : pesticides used $(\mathrm{kg})$. In the estimation process, all variables are transformed by natural logarithms.

\section{Results and Discussion}

\subsection{General Description of Shallot Farming in Indonesia in 2014}

\subsubsection{Harvested area}

In Figures 3 and 4 , it is generally seen that the island of Java has the largest harvested area compared to other islands. The potential for extensive shallot harvest in the dry season is in the provinces of Central Java, East Java, and West Java. In the dry season, the total harvested area in Central Java is $72,980.35$ hectares, East Java is $39,732.48$ hectares, and West Java is $13,179.99$ hectares. While in the wet season, the largest harvested area is in the provinces of Central Java, East Java, and South Sulawesi. The total harvested area in the wet season in Central Java was 53,607.74 hectares, East Java was 11,929.38 hectares, and South Sulawesi was 6,296.67 hectares. 


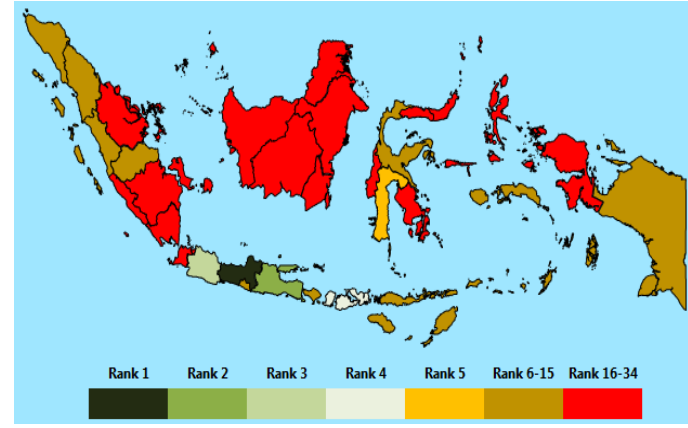

Figure 3. Distribution of shallot harvests in the dry season in Indonesia, 2014

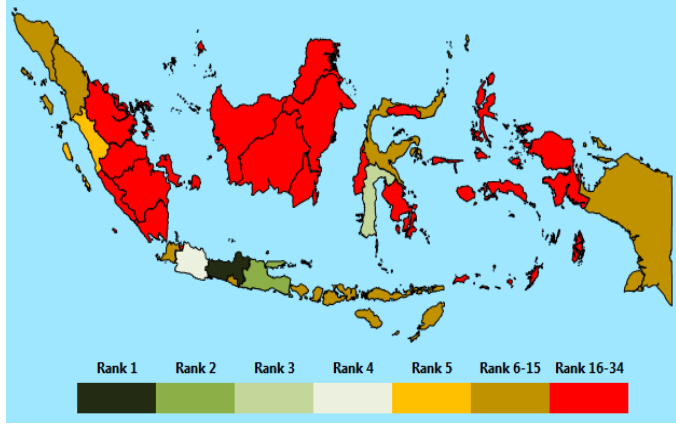

Figure 4. Distribution of shallot harvests in the wet season in Indonesia, 2014

\subsubsection{Production}

In line with the pattern of the wide distribution of harvests in Indonesia, the highest distribution of shallot production is on the island of Java which is spread in the province of Central Java, followed by East Java, then West Java. There is no difference in the distribution pattern of shallot production in the dry season and wet season (See Figure 5 and Figure 6).

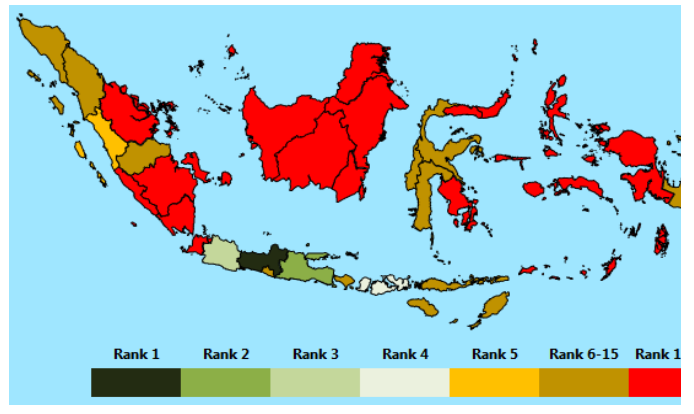

Figure 5. Distribution of shallot production in the dry season in Indonesia, 2014

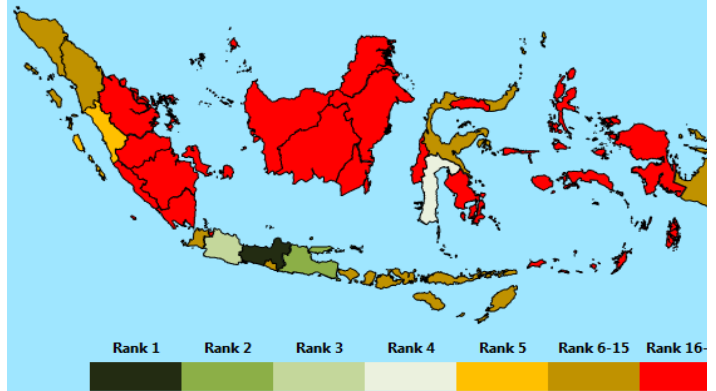

Figure 6. Distribution of shallot production in the wet season in Indonesia, 2014

Other input distributions such as seeds, fertilizers, pesticides, and labor force follow a broad distribution pattern of harvest and production.

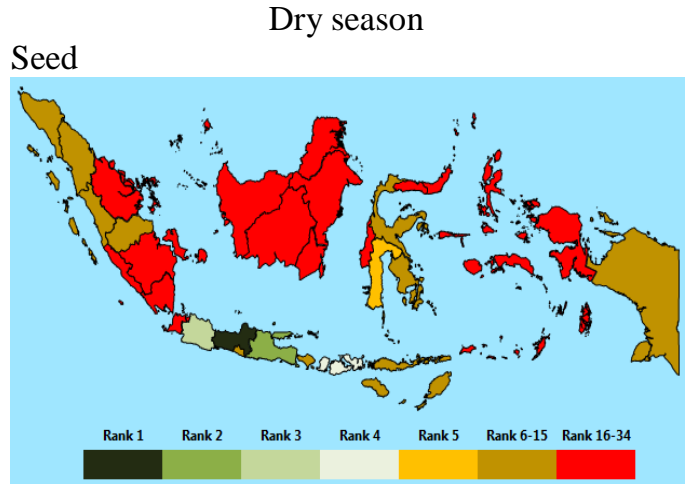

Wet season

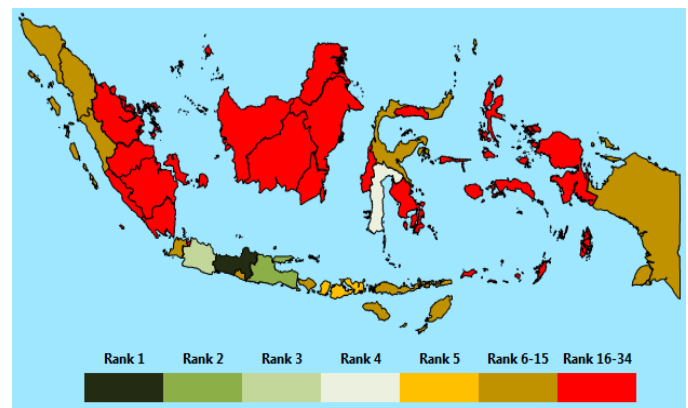




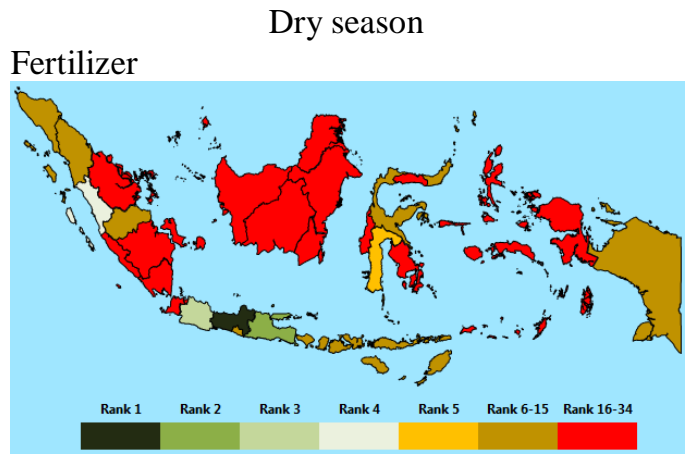

Wet season

Pesticide
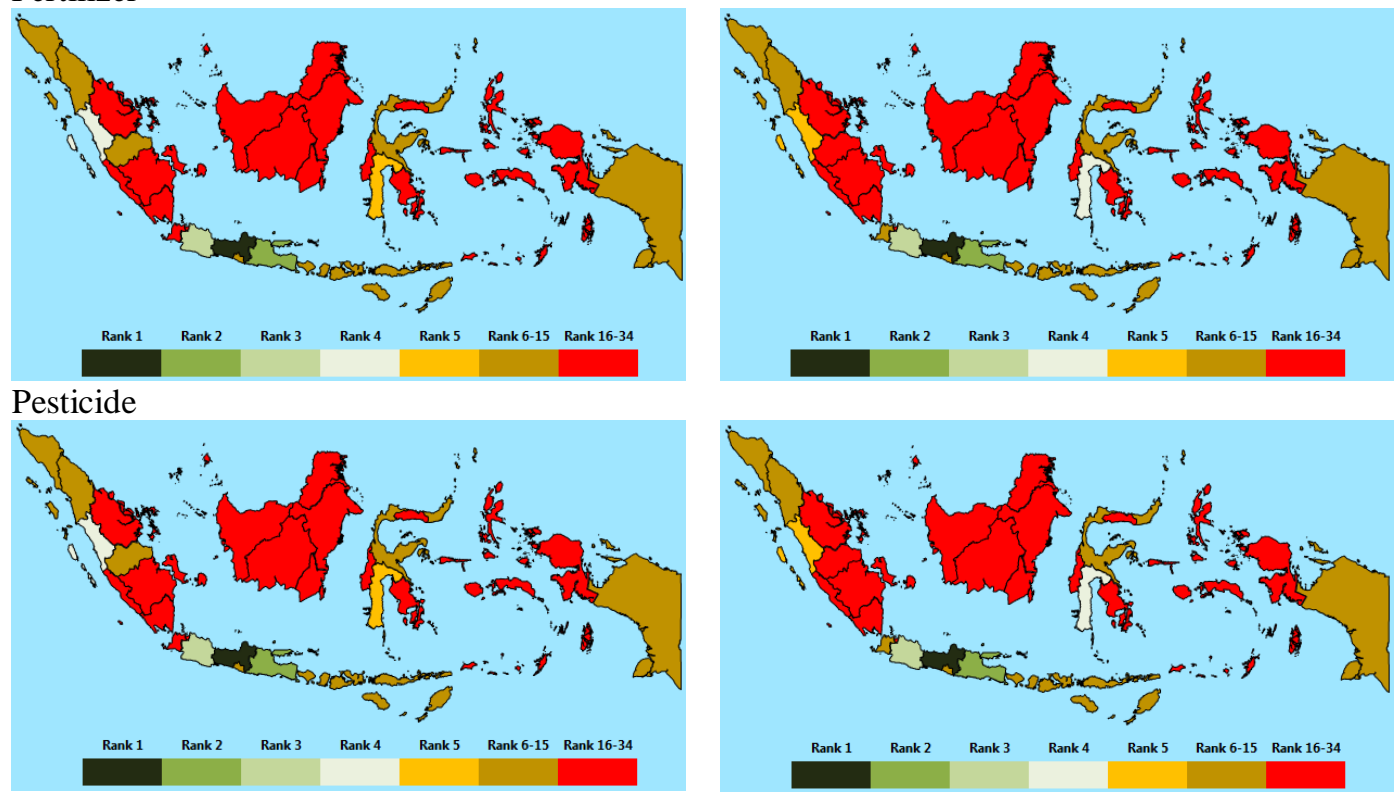

Figure 7. Distribution of shallot seeds, fertilizers, and pesticides in the dry season and wet season in Indonesia, 2014

\subsection{Shallot Cost Structure}

Based on Figure 7, it can be seen that in both seasons, shallot farmers spend more on costs for seeds, labor, and other expenses. In the dry season, expenditures for seeds amounted to 22.85 million rupiahs (35.39 percent), labor wages amounted to 20.18 million rupiahs (31.27 percent), and other expenses amounted to 9.9 million rupiahs (15.36 percent). Other expenses are dominated by land expenditures of 6.8 million rupiahs (68.89 percent), the remainder is for expenses other than land (business equipment, interest on loans, indirect taxes, etc.).

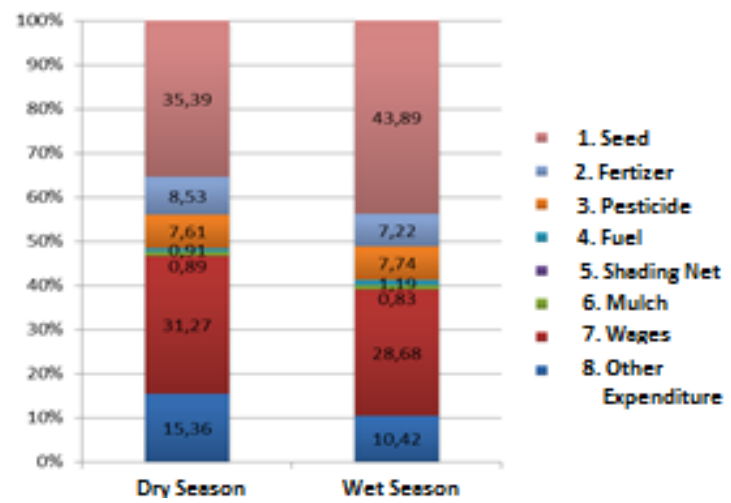

Figure 7. Cost Structure of shallot farming

During the wet season, expenditure on seeds is greater when compared to the dry season. This is because, in the wet season, the land becomes more humid than during the dry season, allowing pests and diseases to develop quickly. As a result, many shallot plants cannot survive, so insertion is necessary (planting new shallots on damaged land) that need more seeds. Therefore, to reduce seed expenditure in the wet season, farmers can use shallot varieties that can survive in the wet season. Seed expenditure in the wet 
season was 31.68 million rupiahs (43.89 percent), labor wages amounted to 20.69 million rupiahs (28.68 percent), and other expenditures amounting to 7.53 million rupiahs (10.42 percent). As with other expenditures in the dry season, other expenses in the wet season are dominated by the land expenditure of 5.18 million rupiahs ( 68.79 percent), the rest for expenditure other than land.

\subsection{Estimated Results of Production Function Parameters Stochastic Frontier Cobb Douglas}

The estimated parameters of the stochastic frontier production function are divided into two, namely the production function during the dry season and the wet season. The following are the results of parameter estimates of the function of shallots production in the dry season.

Table 1. Results of function parameter estimate stochastic frontier cobb Douglass shallot in the dry season

\begin{tabular}{lccc}
\hline \multirow{2}{*}{ Variable } & \multicolumn{3}{c}{ Dry Season } \\
\cline { 2 - 4 } & Coefficient & $\mathrm{Z}$ & $\mathrm{P}>|\mathrm{Z}|$ \\
\hline intercept & 0.5701 & 7.58 & 0.0000 \\
$\log$ (harvested area) & 0.5056 & 37.43 & 0.0000 \\
$\log$ (labor) & 0.2649 & 22.46 & 0.0000 \\
$\log$ (seed) & 0.0952 & 15.82 & 0.0000 \\
$\log$ (fertilizer) & 0.1588 & 22.17 & 0.0000 \\
$\log$ (pesticide) & 0.0370 & 7.50 & 0.0000 \\
$\log$ likelihood & -5911.0601 & & \\
\hline
\end{tabular}

Table 2. Results of function parameter estimate stochastic frontier cobb Douglass shallot in the wet season

\begin{tabular}{lccc}
\hline \multirow{2}{*}{ Variable } & \multicolumn{3}{c}{ Wet season } \\
\cline { 2 - 4 } & Coefficient & $\mathrm{Z}$ & $\mathrm{P}>|\mathrm{Z}|$ \\
\hline intercept & 0.2580 & 2.30 & 0.0217 \\
$\log$ (harvested area) & 0.6002 & 31.29 & 0.0000 \\
$\log$ (labor) & 0.1014 & 6.39 & 0.0000 \\
$\log$ (seed) & 0.1043 & 11.07 & 0.0000 \\
$\log$ (fertilizer) & 0.1599 & 17.44 & 0.0000 \\
$\log$ (pesticide) & 0.0537 & 10.02 & 0.0000 \\
$\log$ likelihood & -2759.7659 & & \\
\hline
\end{tabular}

Table 1 and Table 2 provide information that in both the dry season and the wet season, production inputs, namely harvested area, labor, seeds, fertilizers, and pesticides have a statistically significant effect on shallot production at the five percent significance level. The estimation results produce an input coefficient marked positive. The coefficient on the model (2) is interpreted as the elasticity value of the production input. If the elasticity value is specified according to the type of input, then the value of labor elasticity in the dry season is greater than in the wet season. Meanwhile, the value of the elasticity of the area of harvest, seeds, fertilizers, and pesticides in the wet season is greater than in the dry season. The greatest elasticity value of the five production inputs, both in the dry season and wet season, is the harvest elasticity. Based on the results of parameter estimation, the production function equation is obtained stochastic frontier cobb-Douglass shallots in the dry season as follows:

$$
\begin{aligned}
\text { ln Prod_MK } & 0,5701+0,5056 \times \text { lnHarvestedArea }_{i}+0,2649 \times \operatorname{lnLabor} \\
& +0,0952 \times \text { lnSeed }_{i}+0,1588 \times \text { lnFertilizer }_{i} \\
& +0,037 \times \text { lnPesticide }_{i}
\end{aligned}
$$


Variable harvested area has a coefficient of 0.5056, which means that each addition of harvested area by 1 percent of the harvested area (assuming other inputs remain) can increase production by 0.5056 percent. When compared with other input variable coefficients, the harvested area has the largest coefficient, so it becomes the main influence of increasing production. The wider the area planted is then harvested, the greater the amount of production obtained. Furthermore, labor (HOK) has a coefficient of 0.2649 . The results of this study indicate that each addition of 1 percent of the workforce assuming other inputs is fixed, it will increase production by 0.2649 percent. In the dry season, the workforce is the second variable that has a large contribution to the production of shallots. The use of intensive labor, both paid labor and unpaid labor can provide benefits in the production process. The seed coefficient of 0.0952 indicates that with the assumption that other inputs are fixed, each addition of 1 percent will increase production by 0.0952 percent. The selection of the right seed varieties by soil conditions and quality seeds can increase the productivity of shallots.

The results showed that the amount of fertilizer used had a positive and significant effect on shallot production with a coefficient of 0.1588 . This means that every 1 percent increase in fertilizer, assuming other inputs will continue to increase shallot production by 0.1588 percent. Current conditions, the most use of fertilizer for shallots is NPK fertilizer (22.14 percent) and manure/compost (17.32 percent). According to David Prasatya et al., the use of NPK fertilizer and manure with appropriate doses can increase nitrogen uptake in shallots. Pesticide variable has a coefficient of 0.037 , which means that every 1 percent addition of pesticides will increase shallot production by 0.037 percent assuming other inputs remain. The use of pesticides must follow a certain dose rather, it can protect plants from pests without damaging the organic elements of the soil.

$$
\begin{aligned}
& \text { lnProd_MH }=0,2580+0,6002 \times \text { lnHarvestedArea }{ }_{i}+0,1014 \times \text { lnLabor }_{i} \\
& +0,1043 \times \operatorname{lnSeed}_{i} \times 0,1599 \times \text { lnFertilizer }_{i} \\
& +0,0537 \\
& \times \text { lnPesticide }_{i}
\end{aligned}
$$

In the wet season, the harvested area variable has a coefficient of 0.6002 , which means that each addition of a harvested area of 1 percent of the harvested area (assuming other inputs remain) can increase production by 0.6002 percent. Similar to the production function equation in the dry season, when compared with the other input variable coefficients, the harvested area has the largest coefficient, so that it becomes the main influence of increasing production. Labor (HOK) has a coefficient of 0.1014 . The results of the study show that each addition of 1 percent of the workforce assuming other inputs is fixed, it will increase production by 0.1014 percent. The seed coefficient of 0.1043 shows that assuming other inputs are fixed, each addition of 1 percent will increase production by 0.1043 percent. The selection of shallot seed varieties in the wet season in addition to paying attention to soil conditions, but also must consider the conditions of soil moisture.

The results showed that the amount of fertilizer used had a positive and significant effect on shallot production with a coefficient of 0.1599 . This means that every addition of 1 percent fertilizer with the assumption that other inputs will continue to increase shallot production by 0.1599 percent. Current conditions, the most use of fertilizer used in the wet season for shallots is the same as fertilizer use in the dry season, namely NPK fertilizer (25.08 percent) and manure/compost (13.95 percent). In the wet season, fertilizer has a second important role after the harvested area increases the production of shallots. Therefore, the selection of the right fertilizer must be considered by farmers in the shallot business. Pesticide variables have a coefficient of 0.0537 , which means that every 1 percent addition of pesticides will increase shallot production by 0.0537 percent assuming other inputs remain. 


\subsection{Shallot Technical Efficiency Value}

The following is a table of descriptive statistics on the technical efficiency of shallots in the dry season and the wet season.

Table 3. Results of estimation of the technical efficiency of shallots in the dry season and the wet season

\begin{tabular}{lcc}
\hline \multirow{2}{*}{ Descriptive } & \multicolumn{2}{c}{ Technical Efficiency } \\
\cline { 2 - 3 } & Dry Season & Wet season \\
\hline Mean & 0.6626 & 0.6627 \\
Median & 0.7212 & 0.7202 \\
Minimum & 0.0106 & 0.0188 \\
Maksimum & 0.9320 & 0.9385 \\
Standar deviasi & 0.1772 & 0.1836 \\
$n$ & 6.289 & 3.135 \\
\hline
\end{tabular}

Based on the table, the technical efficiency of shallot farming in the dry and wet season is 0.6626 and 0.6627 , respectively. There is no significant difference in the average technical efficiency in both seasons. The coefficient of 0.6626 (in the dry season) and 0.6627 (in the wet season) shows that households are only able to achieve the realization of production of 66.26 percent or 66.27 percent of the input owned. Based on the specified criteria [8], information can be obtained that in general, the shallot farming in Indonesia is not efficient on the technical side. That is, there are indications that the optimal processing technology of production inputs in the business has not been carried out optimally. To examine what factors cause technically inefficient production of shallots, further research needs to be done.

\section{Conclusion}

Based on the discussion it can be concluded that the estimation of the function of shallot production, both for the dry season and the wet season with independent variables include harvested area, labor, labor, seeds, fertilizers, and significant pesticides in the model so that the formed model is valid for further use. The average technical efficiency of shallot farming in the dry and wet season is 0.6626 and 0.6627 , respectively, which means that in general, the shallot farming in Indonesia is not efficient on the technical side. That is, there are indications that the optimal processing technology of production inputs in the business has not been carried out optimally.

\section{References}

[1] A.Y. Kurniawan, Analisis efisiensi ekonomi dan daya saing usaha tani jagung pada lahan kering di Kabupaten Tanah Laut Kalimantan Selatan [tesis]. Institut Pertanian Bogor, 2008.

[2] C.W. Cobb, and P. H. Douglas, A Theory of production. American Economic Review. 18 (Supplement): 139-165. 1928. Retrieved 26 September 2016.

[3] D.J. Aigner, C.A.K. Lovell, and P. Schmidt, "Formulation and estimation of stochastic frontier production function models," Journal of Econometrics 6, pp. 21-37, 1977.

[4] D. Prasetya, I. Wahyudi and Baharudin, "Pengaruh Jenis Dan Komposisi Pupuk Kandang Ayam Dan Pupuk Npk Terhadap Serapan Nitrogen Dan Hasil Bawang Merah (Allium Ascalonicum L.) Varietas Lembah Palu Di Entisol Sidera," 384e-J. Agrotekbis vol. 4, no.4, pp.384-393, 2016. Diambil dari : https://media.neliti.com/media/publications/244715-pengaruh-jenis-dan-komposisipupuk-kanda-65b1517b.pdf. (22 Februari 2019). 
[5] J. Jondrow, C.A.K. Lovell, I.S. Materov, and P. Schmidt, "On the estimation of technical inefficiency in the stochastic frontier production function model," Journal of Econometrics 19, pp. 233-238, 1982.

[6] J. Marschak, and W.J. Andrews, "Random simultaneous equations and the theory of production," Econometrica 12, pp. 143-205, 1944.

[7] M. Daniel, Pengantar Ekonomi Pertanian. PT Bumi aksara, 2002

[8] K.A. Bakhsh, and B. Ahmad, 2006, "Technical efficiency and its determinant in potato production, evidence from Punjab, Pakistan," The Lahor Journal of Economics, vol.11, no.2 [Winter 2006], pp. 1-22, 2006.

[9] P.C. Kindleberger and B. Herrick, Economic Development. Tokyo Printing, 1977.

[10] R.E. Stevenson, R.E., "Likelihood functions for generalized stochastic frontier estimation," J.Econometrics13, pp. 57-66, 1980.

[11] R.L. Miller and R.E. Meiner, Teori Mikro Ekonomi. Raja Grafindo, 2000.

[12] Soekartawi, Teori Ekonomi Produksi Dengan Pokok Bahasan Analisis Fungsi Cobb-Duoglas. CV Rajawali, 2003.

[13] W. Nicholson, Mikroekonomi Intermediate dan Aplikasinya. Erlangga, 2002. 